\title{
Analisis Faktor Fundamental Pertumbuhan Perusahaan PT. Bukit Asam (Persero) Tbk
}

\author{
Destia Aktarina \\ AKUBANK Mulia Darma Pratama Palembang \\ email: destiaaktarina86@gmail.com
}

\begin{abstract}
ABSTRAK
Pertumbuhan perusahaan akan menimbulkan konsekuensi pada peningkatan investasi atas aset perusahaan dan akhirnya membutuhkan penyediaan dana untuk membeli aset. Pertumbuhan perusahaan sangat diharapkan oleh pihak internal maupun eksternal perusahaan, karena pertumbuhan yang baik memberi tanda bagi perkembangan perusahaan. Menganalisis pertumbuhan dapat melihat dari faktor fundamental suatu perusahaan, dimana faktor fundamental pertumbuhan perusahaan yakni Growth In Equity Earnings dan Growth In Operating Income, dimana Growth In Equity Earnings terdiri dari pertumbuhan dalam earning per share dan pertumbuhan dalam net income sedangkan Growth In Operating Income terdiri dari skenario Return On Capital yang stabil dan skenario Return On Capital yang berubah dan positif. Penelitian ini menggunakan data sekunder dengan cara kepustakaan yakni pengumpulan data dengan mempelajari masalah-masalah yang berhubungan dengan objek yang diteliti melalui internet, buku-buku pedoman dll. Dari hasil penelitian menunjukkan bahwa pertumbuhan perusahaan pada PT. Bukit Asam (Persero) Tbk dapat ditentukan dengan melihat faktor fundamental pertumbuhan perusahaan, semakin tinggi jumlah laba bersih dan EPS Perusahaan maka tingkat pertumbuhan perusahaan akan mengalamai peningkatan.
\end{abstract}

Kata Kunci : growth in equity earnings, growth in operating income dan pertumbuhan perusahaan

\section{A. Latar Belakang}

Perusahaan yang tumbuh dengan cepat memperoleh hasil positif dalam artian pemantapan posisi di peta persaingan dan juga memiliki keuntungan positif yang diperoleh, akan tetapi perusahaan juga harus hati-hati, karena kesuksesan yang diperoleh menyebabkan perusahaan menjadi rentan terhadap isu negatif. Beberapa hal yang perlu mendapat perhatian penting karena dapat merupakan sumber berita negatif yang menggambarkan kemampuan perusahaan untuk mempertahankan, mengembangkan dan membangun kecocokan kualitas dan pelayanan dengan harapan konsumen. Pertumbuhan yang cepat juga memaksa sumber daya manusiayang dimiliki untuk secara optimal memberikan kontribusinya. Pertumbuhan perusahaan sangat diharapkan oleh pihak internal maupun eksternal perusahaan, karena pertumbuhan yang baik memberi tanda bagi perkembangan perusahaan.

Menurut Harahap (2013:87), Growth (pertumbuhan) merupakan indikator bagi maju tidaknya suatu perusahaan. Suatu perusahaan dengan pertumbuhan yang positif (trennya meningkat) adalah indikator majunya perusahaan tersebut. Perusahaan dengan pertumbuhan yang tinggi biasanya menggunakan hutang dalam jumlah besar, karena biaya pengembangan pada emisi saham biasa lebih tinggi dibandingkan dengan emisi obligasi. Laju pertumbuhan suatu perusahaan akan mempengaruhi kemampuan perusahaan mempertahankan keuntungan dalam mendanai kesempatan-kesempatan pada masa yang akan datang. 
Pertumbuhan perusahaan sangat diharapkan oleh pihak internal maupun eksternal suatu perusahaan karena dapat memberikan suatu aspek yang positif bagi mereka. Dilihat dari sudut pandang investor, pertumbuhan suatu perusahaan merupakan tanda bahwa perusahaan memiliki aspek yang menguntungkan, dan mereka mengharapkan rate of return (tingkat pengembalian) dari investasi mereka memberikan hasil yang lebih baik, Sriwardany (2007).

Pertumbuhan

perusahaan

merupakan kemampuan perusahaan untuk meningkatkan size (Kaliapur dan Trombley, 2001). Pertumbuhan perusahaan akan menimbulkan konsekuensi pada peningkatan investasi atas aset perusahaan dan akhirnya membutuhkan penyediaan dana untuk membeli aset.

Menurut Murhadi (2013;98), faktor fundamental dari pertumbuhan yakni Growth in Equity Earning dan Growth in Operating Income. Growth in Equity Earningsmerupakan pendapatan dari pemegang saham yang dapat dilihat dari net income, dan dalam hal ini growth in equity earnings dapat dibagi menjadi 2 (dua) : yakni pertumbuhan dalam earning per share (EPS) dan pertumbuhan dalam net income. Pertumbuhan dalam earning per share (EPS) dimana hubungan sederhana untuk menentukan tingkat pertumbuhan adalah dengan mendasarkan pada retention ratio (persentase dari earning yang ditahan untuk pengembangan usaha) dan return on equity-ROE (tingkat pengembalian dari modal yang telah ditanamkan). Perusahaan dengan retention ratio yang tinggi dan diikuti pula ROE yang tinggi akan memberikan tingkat pertumbuhan yang tinggi pula dalam earning per share (EPS).
Pertumbuhan dalam net income dimana bila analisis melakukan relaksasi terhadap asumsi sumber dari ekuitas adalah retained earning, maka pertumbuhan dalam net income dapat berbeda dari pertumbuhan EPS. Secara intuisi, bila perusahaan menerbitkan saham baru maka pertumbuhan net income dapat meningkat relatif, sementara pertumbuhan earning per share (EPS) relatif stagnan. Untuk menurunkan hubungan antara pertumbuhan net income dengan fundamental perusahaan, maka dibutuhkan ukuran tingkat investasi yang dilakukan. Salah satu cara untuk mengestimasi secara langsung bagaimana perusahaan melakukan re-investasi adalah melihat pada Net Capex dan investasi working capital.

Growth in Operating Income dimana untuk menentukan pertumbuhan, maka disusun dua skenario yaitu : pertama, ketika perusahaan mengalami return on capital(ROC) yang tinggi dan kemudian diharapkan bertahan dalam jangka waktu berikutnya. Kedua, ketika perusahaan mendapatkan positif return on capitaldan diharapkan untuk meningkat pada periode waktu berikutnya.

PT. Bukit ASAM (Persero) Tbk merupakan perusahaan industri yang berada di Tanjung Enim, Sumatera Selatan. PT. Bukit Asam perusahaan BUMN yang dimiliki Indonesia, perusahaan ini bergerak dibidang pertambangan batubara yang dari segi penjualan PTBA untuk periode Januari-Desember 2013 naik sebesar 26 persen atau menjadi 17,84 juta ton dibandingkan penjualan diperiode yang sama tahun 2012 sebesar 14,15 juta ton. Sementara dari sisi produksi dan pembelian batubara selama periode Januari-Desember 2013 tercatat sebesar 17,78 juta ton, naik 15 persen 
dibandingkan produksi dan pembelian batubara tahun sebelumnya yang mencapai 15,46 juta ton.PT Bukit Asam (Persero) Tbk (PTBA) menargetkan penjualan batu bara naik 51 persen dari 19,1 juta ton di 2015 menjadi 29,17 juta ton pada tahun ini 2016.

Krisis harga batubara telah melanda seluruh industri batubara dunia, termasuk industri batubara Indonesia. Dalam hal ini PTBA merupakan satu-satunya perusahaan yang paling berhasil dalam pengendalian kinerja keuangannya. Posisi PTBA berhasil mencatat perolehan laba bersih untuk periode Januari-September 2013 sebesar Rp. 1,4 triliun. Keberhasilan PTBA tersebut adalah berkat langkah-langkah strategis yangdiambil perusahaan, di antaranya dengan memberikan prioritas penjualan batubara kalori tinggi yang banyak diminati pasar ekspor.

Keadaan keuangan PT.Tambang Bukit Asam (persero) Tbk, yakni Total Asset pada tahun 2010 Rp. 8.722.699 mengalami kenaikan menjadi Rp.14.812.023 pada tahun 2014. Kenaikan asset lancar dari tahun 2010 ke 2014 naik sebesar $41.11 \%$. total utang dari tahun 2010 adalah $\mathrm{Rp}$. 2.281.451 mengalami kenaikan di tahun 2014 menjadi Rp. 6.141.181 sehingga dapat dikatakan utang usaha mengalami kenaikan sebesar $62.84 \%$. Total modal dari tahun 2010 sampai 2014 hampir selalu mengalami kenaikan, kecuali pada tahun 2013 saja yang mengalami penurunan dari tahun sebelumnya. Total persediaan tahun 2010 senilai Rp. 423.678 mengalami kenaikan ditahun 2014 menjadi Rp. 1.033.360, sehingga dapat dikatakan total persediaan mengalami kenaikan Rp.58.99\%. Total pendapatan uasah tahun 2010 senilai Rp.2.304.158 mengalami kenaikan sebesar Rp.2.310.198 pada tahun 2014. Sehingga dapat dikatakan total pendapatan usaha mengalami kenaikan sebesar $0.26 \%$. Meskipun utang dalam PT.Bukit Asam (persero)Tbk, mengalami kenaikan sebesar $62.84 \%$ namun pendapatan juga mengalami kenaikan walaupun hanya sebesar $0.26 \%$ dari tahun 2010 menuju tahun 2014. Total Asset yang didapatkan oleh PT.Bukit Asam (persero)Tbk, mengalami kenaikan sebesar $41.11 \%$.

\section{B. Metode Penelitian \\ 1) Objek Penelitian}

Penelitian ini dilakukan pada PT. Bukit Asam (Persero) Tbk. Jl. Parigi No. 1 Tanjung Enim 31716, Sumatera Selatan Sebagai objek penelitian.

\section{2) Sumber data}

Sumber data yang digunakan dalam penelitian ini adalah data sekunder yakni yang berupa data-data yang berasal dari situs internet seperti www.idx.co.idwww.bps.go.id.

\section{Teknik Pengumpulan Data}

Adapun metode pengumpulan data yang digunakan dalam penelitian ini adalah kepustakaan (Liberary Research), yaitu pengumpulan data dengan mempelajari masalah-masalah yang berhubungan dengan objek yang diteliti melalui internet, buku-buku pedoman, majalah dan bahan-bahan lainnya yang berhubungan dengan penelitian.

\section{Teknik Analisis Data}

Teknik analisis yang digunakan untuk permasalahan dan penelitian ini adalah teknik analisis kualitatif. Teknik analisis kualitatif adalah suatu metode yang dimulai dengan cara mengumpulkan data, mencatat data, mengklasifikasikan data dan 
menganalisis data berdasarkan permasalahan yang telah dirumuskan, kemudian menarik kesimpulan dari yang dianalisis dalam penelitian.

Adapun langkah-langkah untuk menjawab perumusan masalah yaitu bagaimana faktor fundamental pertumbuhan perusahaan pada PT. Bukit Asam (Persero) Tbk. Dapat dilihat dari :

\section{Growth in Equity Earning}

Dapat dibagi menjadi dua yakni pertumbuhan dalam earning per share (EPS) dan pertumbuhan dalam net income.

a. Pertumbuhan dalam Earning Per Share (EPS)

$g_{t}=\frac{\mathrm{NI}_{\mathrm{t}}-\mathrm{NI}_{\mathrm{t}-1}}{\mathrm{NI}_{\mathrm{t}-1}}$

Dimana :

$\mathrm{G}_{\mathrm{t}}=$ tingkat pertumbuhan dalam net income

$\mathrm{Nl}=$ net income pada tahun $\mathrm{t}$

b. Pertumbuhan dalam net income

Ekuitas yang diinvestasikan kembali dalam bisnis = Net capex + perubahan dalam working capital - (utang baru yang diterbitkan - utang yang dibayarkan).

Dimana : Net Capex adalah sebuah belanja modal untuk membeli aset tetap atau menambah nilai aset tetap yang ada dengan masa manfaat yang meluas dari tahun pajak capital expenditure digunakan oleh perusahaan untuk memperoleh atau meng-upgrade fisik aset seperti peralatan, properti dan bangunan industri dll.

Dan pertumbuhan yang diharapkan dari net income = Tingkat re-investasi ekuitas $x$ ROE.

2. Growth in Operating Income

Pertumbuhan income bagi pemegang saham ditentukan dari besarnya modal yang diinvestasikan kembali ke dalam bisnis dan tingkat hasil dari equity investment. Untuk menentukan pertumbuhan dibuatlah dua skenario.

a. Skenario return on capital yang stabil

Tingkat pertumbuhan yang diharapkan

$=$ Reinvestment Rate $\times$ ROC

Dimana :

Reinvestment rate =

Net Capex + Noncash Working Capital

ROC $=$ EBIT (1-tax) $/$ capital invested

b. Skenario Return on Capital yang berubah dan positif

Tingkat pertumbuhan yang diharapakan :

$=$ ROCt $\times$ Reinvestment rate + $\frac{\mathrm{ROC}_{t}-R O C_{t-1}}{R O C_{t-1}}$

\section{E. Hasil Penelitian}

Dari hasil penelitian yang telah penulis lakukan dan juga di dapat datadata yang telah dilakukan perhitungan berdasarkan analisis yang digunakan. Berdasarkan data yang ada, analisis yang akan diuji dalam penelitian ini berkaitan mengenai analisa faktor fundamental pertumbuhan perusahaan pada PT. Bukit Asam (Persero) Tbk. Analisis ini dilakukan dengan perhitungan berdasarkan data-data dan alat analisis yang digunakan yaitu analisis kualitatif.Dalam menganalisis pertumbuhan dapat melihat dari faktor fundamental suatu perusahaan, dimana faktor fundamental pertumbuhan suatu perusahaan yang antara lain :

\section{Growth In Equity Earnings}

Merupakan pendapatan bagi pemegang saham yang dapat dilihat dari net income. Dimana growth in equity earnings dapat dibagi menjadi 2 yakni pertumbuhan dalam Earning $\mathrm{Per}$ 
Share (EPS) dan pertumbuhan dalam net income.

\section{Pertumbuhan Dalam EPS (Earning Per Share)}

Earning Per Share adalah pendapatan per lembar saham yang dapat dilihat di laporan laba rugi. Dimana EPS (Earning Per Share) pada PT.Bukit Asam (Persero) Tbk dapat dilihat pada tabel di bawah ini :

Tabel 1

EPS (Earning Per Share) PT. Bukit Asam (Persero) Tbk Tahun 2010-2014

(dalam jutaan rupiah)

\begin{tabular}{|c|c|c|}
\hline Tahun & $\begin{array}{c}\text { Earning Per } \\
\text { Share (EPS) }\end{array}$ & $\begin{array}{c}\text { Kenaikan/ } \\
\text { penurunan }\end{array}$ \\
\hline 2009 & 1.184 & - \\
\hline 2010 & 872 & $(26.35 \%)$ \\
\hline 2011 & 1.339 & $53.55 \%$ \\
\hline 2012 & 1.262 & $(5.75 \%)$ \\
\hline 2013 & 822 & $(34.36 . \%)$ \\
\hline 2014 & 927 & $12.77 \%$ \\
\hline
\end{tabular}

Sumber : Laporan Keuangan PT. Bukit Asam (Persero) Tbk

Pada tabel dapat dilihat pendapatan per lembar saham pada PT. Bukit Asam (Persero) Tbk mengalami naik turun. Pada tahun 2009 Earning Per Share sebesar Rp.1.184 dan Pada tahun 2010 EPS sebesar Rp.872 mengalami penurunan sebesar $26.35 \%$ dari tahun 2009. Pada tahun 2011 Earning Per Share PT.Bukit Asam (Persero) Tbk sebesar Rp.1.339 mengalami peningkatan $53.55 \%$ dari tahun 2010, Pada tahun 2012 sebesar Rp.1.262 mengalami penurunan $5.75 \%$ dari tahun 2011. Sedangkan pada tahun 2013 Earning Per Share PT.Bukit Asam (Persero) Tbk sebesar RP.822 mengalami penurunan $34.36 \%$ dari tahun 2012, Pada tahun 2014 Earning Per Share sebesar Rp.927 mengalami peningkatan $12.77 \%$ dari tahun 2013 . Dari perhitungan diatas, penyebab naik turunya Earning Per Share (EPS) PT.Bukit Asam (Persero) Tbk dilihat dari jumlah Net Income (laba bersih) yang diperoleh PT. Bukit Asam (Persero) Tbk yang mengalami naik turun dari setiap tahunnya. Hal tersebut mengakibatkan perubahan
Earning Per Share (EPS) pada PT.Bukit Asam (Persero) Tbk.

Untuk melihat pertumbuhan Earning Per Share (EPS) PT.Bukit Asam (Persero) Tbk dapat dihitung dengan menggunakan rumus :

$$
g_{t}=\frac{\left(E P S_{t}-E P S_{t-1}\right)}{E P S_{t-1}}
$$

EPS pada tahun 2010

$=\frac{872-1.184}{1.184} \times 100 \%=-26.35 \%$

EPS pada tahun 2011

$=\frac{1.339-872}{872} \times 100 \%=53.55 \%$

EPS pada tahun 2012

$=\frac{1.262-1.339}{1.339} \times 100 \%=-5.75 \%$

EPS pada tahun 2013

$=\frac{822-1.262}{1.262} \times 100 \%=-34.86 \%$

EPS pada tahun 2014

$=\frac{927-822}{822} \times 100 \%=12.77 \%$

Untuk lebih jelasnya dapat dilihat pada tabel 2 sebagai berikut : 


\section{Tabel 2}

Pertumbuhan dalam Earning Per Share (EPS) PT. Bukit Asam (Pesero) Tbk

Tahun 2010-2014

\begin{tabular}{|c|c|}
\hline Tahun & $\begin{array}{c}\text { Pertumbuhan EPS } \\
\text { (Earning Per Share) }\end{array}$ \\
\hline 2010 & $-26.35 \%$ \\
\hline 2011 & $53.55 \%$ \\
\hline 2012 & $-5.75 \%$ \\
\hline 2013 & $-34.86 \%$ \\
\hline 2014 & $12.77 \%$ \\
\hline & Sumber : data diolah \\
\hline
\end{tabular}

Pada tabel di atas dapat dilihat bahwa pada tahun 2010 pertumbuhan EPS pada PT.Bukit Asam (Persero) Tbk sebesar $-26.35 \%$, sedangkan pada tahun 2011 pertumbuhan Earning Per Share PT.Bukit Asam (Persero) Tbk sebesar 53.55\%. Pada tahun 2012 pertumbuhan Earning Per Share menjadi sebesar $-5.75 \%$, dan tahun 2013 pertumbuhan EPS sebesar 34.86\%. Pada tahun 2014 pertumbuhan Earning Per Share (EPS) sebesar $12.77 \%$.

\section{Pertumbuhan Dalam Net Income}

Net Income merupakan laba setelah pajak yang dapat dilihat di laporan laba rugi. Dimana Net Income PTBukit Asam (Persero)Tbk tahun 2010 sampai dengan 2014 dapat dilihat pada tabel di bawah ini :

Tabel 3

Net Income PT. Bukit Asam (Persero) Tbk Tahun 2010-2014 (dalam jutaan rupiah)

\begin{tabular}{|c|c|c|}
\hline Tahun & Net Income (NI) & Kenaikan / Penurunan \\
\hline 2009 & 2.729 .327 & - \\
\hline 2010 & 1.998 .937 & $26.76 \%$ \\
\hline 2011 & 3.088 .068 & $54.48 \%$ \\
\hline 2012 & 2.909 .421 & $5.78 \%$ \\
\hline 2013 & 1.854 .281 & $36.26 \%$ \\
\hline 2014 & 2.019 .214 & $8.89 \%$ \\
\hline
\end{tabular}

Sumber : Laporan Keuangan PT. Bukit Asam (Persero) Tbk

Pada tabel 3 dapat dilihat bahwa net income pada PT.Bukit Asam (Persero) Tbk mengalami fluktuasi naik turun. Pada tahun 2009 Net Income sebesar Rp.2.729.327. Pada tahun 2010 Net Income sebesar Rp.1.998.937 mengalami penurunan $26.76 \%$ dari tahun 2009. Dan net income pada tahun 2011 sebesar Rp.3.088.068 mengalami peningkatan $54.48 \%$ dari tahun 2010. Pada tahun 2012 net income sebesar Rp.2.909.421 mengalami penurunan
$5.78 \%$ dari tahun 2011. Pada tahun 2013 net income sebesar Rp.1.854.281 mengalami penurunan $36.26 \%$ dari tahun 2012. Pada tahun 2014 net incomepada PT.Bukit Asam (persero) Tbk sebesar Rp.2.019.214 mengalami peningkatan $8.89 \%$ dari tahun 2013.

Untuk melihat tingkat pertumbuhan Net Income pada PT.Bukit Asam (Persero) Tbk dapat menggunakan rumus sebagai berikut : 
Dimana :

$$
g_{t} \frac{\left(N I_{t}-N I_{t-1}\right)}{N I_{t-1}}
$$

$\mathrm{G}_{\mathrm{t}}=$ Tingkat pertumbuhan dalam Net Income

$\mathrm{Nl}_{\mathrm{t}}=$ net income pada tahun $\mathrm{t}$

Net Income pada tahun 2010

$=\frac{1.998 .937-2.729 .327}{2.729 .327} \times 100 \%=-26.4 \%$

Net Income pada tahun 2011

$=\frac{3.088 .068-1.998 .937}{1.998 .937} \times 100 \%=53.6 \%$

Net Income pada tahun 2012 $=\frac{2.909 .421-3.088 .068}{3.088 .068} \times 100 \%=-6.00 \%$

Net Income pada tahun 2013

$=\frac{1.854 .281-2.909 .421}{2.909 .421} \times 100 \%=-37.00 \%$

Net Income pada tahun 2014

$=\frac{2.019 .214-1.854 .281}{1.854 .281} \times 100 \%=10.4 \%$

Untuk lebih jelasnya perhitungan data tingkat pertumbuhan Net Income pada PT. Bukit Asam (Persero) Tbk dapat dilihat pada tabel 4 sebagai berikut :

Tabel 4

Tingkat Pertumbuhan Net Income PT. Bukit Asam (Persero) Tbk

Tahun 2010-2014

(dalam persen)

\begin{tabular}{|c|c|}
\hline Tahun & Pertumbuhan Net Income \\
\hline 2010 & $(26.4)$ \\
\hline 2011 & 53.6 \\
\hline 2012 & $(6.0)$ \\
\hline 2013 & $(37.0)$ \\
\hline 2014 & 10,4 \\
\hline
\end{tabular}

Sumber : Laporan Keuangan PT. Bukit Asam (Persero) Tbk

Pada tabel 4 dapat dilihat bahwa pertumbuhan net income pada PT. Bukit Asam (persero) Tbk. Dimana pada tahun 2010 net income sebesar $26,4 \%$ pada tahun 2011 tingkat pertumbuhan net incomesebesar $53,6 \%$ mengalami peningkatan $27.2 \%$ dari tahun 2010. Dan tahun 2012 tingkat pertumbuhan net income sebesar $6,0 \%$ mengalami penurunan 47.6\% dari tahun 2011.
Pada tahun 2013 pertumbuhan net income sebesar $37,0 \%$ mengalami penurunan 31\%dari tahun 2012. Dan pada tahun 2014 pertumbuhan net income sebesar $10,4 \%$ mengalami peningkatan $26.6 \%$ dari tahun 2013 .

\section{Deskripsi Pertumbuhan Yang Diharapkan Dari Net Income \\ Pada pertumbuhan yang diharapkan dari Net Income dapat dilihat pada tabel berikut :}




\section{Tabel 5}

Pertumbuhan Yang Diharapkan Dari Net Income

Pada PT.Bukit Asam (Persero) Tbk Tahun 2010-2014

(dalam jutaan rupiah)

\begin{tabular}{|c|c|c|c|c|c|c|c|}
\hline & $\begin{array}{c}\text { Net } \\
\text { Income }\end{array}$ & $\begin{array}{c}\text { Net } \\
\text { Capex }\end{array}$ & $\begin{array}{c}\text { Change } \\
\text { in WC }\end{array}$ & $\begin{array}{c}\text { New } \\
\text { debt } \\
\text { issued }\end{array}$ & $\begin{array}{c}\text { Equity } \\
\text { Reinvestment } \\
\text { rate }\end{array}$ & ROE & $\begin{array}{c}\text { Expected } \\
\text { Growth } \\
\text { Rate dari } \\
\text { Net } \\
\text { Income } \\
(7)=(5)^{\star}(6)\end{array}$ \\
\hline 2010 & 1.998 .937 & 610.556 & 5.498 .225 & 675.079 & $339.37 \%$ & $31.03 \%$ & $105.30 \%$ \\
\hline 2011 & 3.088 .068 & 583.112 & 6.941 .732 & 1.133 .388 & $280.37 \%$ & $37.83 \%$ & $106.06 \%$ \\
\hline 2012 & 2.909 .421 & 1.185 .213 & 6.847 .883 & 1.059 .561 & $312.52 \%$ & $34.21 \%$ & $106.91 \%$ \\
\hline 2013 & 1.854 .281 & 1.394 .080 & 4.218 .827 & 610.186 & $335.61 \%$ & $24.55 \%$ & $82.39 \%$ \\
\hline 2014 & 2.019 .214 & 1.036 .002 & 3.842 .676 & 658.260 & $274.21 \%$ & $23.28 \%$ & $63.83 \%$ \\
\hline
\end{tabular}

Sumber : data diolah

Pertumbuhan yang diharapkan dari net income dapat ditulis sebagai berikut:

Pertumbuhan yang diharapkan dari net income $=$ Tingkat $r$-investasi ekuitas $\times$ ROE

Expected Growth rate pada tahun 2010 $=339.37 \% \times 31.03 \%=105.30 \%$

Expected Growth rate pada tahun 2011 $=280.37 \% \times 37.83 \%=106.06 \%$

Expected Growth rate pada tahun 2012 $=312.52 \% \times 34.21 \%=106.91 \%$

Expected Growth rate pada tahun 2013 $=335.61 \% \times 24.55 \%=82.39 \%$

Expected Growth rate pada tahun 2014 $=274.21 \% \times 23.28 \%=63.83 \%$

Pada tabel 5 di atas dapat dilihat bahwa pertumbuhan yang diharapkan dari net income pada PT.Bukit Asam (Persero) Tbk mengalami perubahan yang fluktuasi. Dimana pada tahun 2010 pertumbuhan yang diharapkan sebesar $105.30 \%$ dan pada tahun 2011 mengalami kenaikan pertumbuhan yang diharapkan dari net income sebesar $106.06 \%$.

Pada tahun 2012 juga mengalami kenaikan sebesar 106.91\%, sedangkan pada tahun 2013 pertumbuhan yang diharapkan mengalami penurunan sebesar 82.39\% dan pada tahun 2014 juga mengalami penurunan terhadap pertumbuhan yang diharapkan dari net income sebesar $63.83 \%$. Dimana tingkat pertumbuhan yang diharapkan dari Net Incomedipengaruhi dari seberapa besar ROE yang diperoleh PT.Bukit Asam (Persero) Tbk. Dengan kata lain, meningkatnya leverage dalam batas waktu tertentu akan meningkatkan ROE bila manfaat dari penggunaan utang lebih besar dari pada bunga utang. Dari data diatas dapat dilihat tingkat pertumbuhan yang diharapkan dari Net Incomeyang melebihi dari seratus persen itu menandakan bahwa laba perusahaan melebihi target pencapaian yang diharapkan, dapat dikatakan bahwa pada tahun tersebut mendapatkan laba yang optimal yang di peroleh PT.Bukit Asam (Persero) Tbk. Laba tersebut dapat di investasikan kembali dengan menambah asset tetap perusahaan atau juga dapat digunakan untuk mensejahterakan para pemegang saham perusahaan. Oleh sebab itu, semakin tinggi pendapatan atau laba yang diperoleh perusahaan semakin besar tingkat pertumbuhan perusahaan.

\section{Deskripsi Growth In Operating Income}


Pertumbuhan income bagi pemegang saham ditentukan dari besarnya modal yang diinvestasikan kembali ke dalam bisnis dan tingkat hasil dari equity investment.

\section{Skenario Return On Capital Yang Stabil}

Perusahaan mengalami return on capital yang stabil, maka pertumbuhan yang diharapkan dalam operating income adalah bersumber dari tingkat re-investasi dan kualitas dari reinvestasi, yang diukur sebagai Return On Capital (ROC) yang divestasikan. Untuk mengetahui hal tersebut dapat dilihat dari rumus sebagai berikut :

Tingkat Pertumbuhan yang Diharapkan EBIT $=$ Reinvestment Rate $\mathrm{x}$ ROC

Untuk melihat Return On Capital (ROC) dapat dilihat pada tabel 6 di bawah ini :

Tabel 6

Return On Capital PT. Bukit Asam (persero) Tbk

Tahun 2010-2014

\begin{tabular}{|c|c|c|c|c|c|}
\hline & EBIT & $\begin{array}{c}\text { EBIT(1-tax) } \\
\text { tax. 20\% } \\
(2)\end{array}$ & BV of Debt & BV of Equity & ROC \\
\hline 2010 & 2.304 .158 .000 & 1.843 .326 .400 & 2.281 .451 .000 & 2.795 .520 .579 & $(5)=(2) /(3+4)$ \\
\hline 2011 & 3.741 .059 .000 & 2.992 .874 .200 & 3.348 .092 .000 & 3.542 .450 .789 & $43.43 \%$ \\
\hline 2012 & 3.593 .510 .000 & 2.874 .808 .000 & 4.223 .812 .000 & 3.691 .268 .364 & $36.32 \%$ \\
\hline 2013 & 2.152 .838 .000 & 1.722 .270 .400 & 4.125 .586 .000 & 3.277 .403 .159 & $23.26 \%$ \\
\hline 2014 & 2.310 .198 .000 & 1.848 .158 .400 & 6.141 .181 .000 & 3.763 .170 .933 & $18.66 \%$ \\
\hline
\end{tabular}

Sumber : data diolah

Untuk melihat Return On Capital (ROC) dapat menggunakan rumus sebagai berikut :

ROC = EBIT (1-tax) / Capital invested

Dimana :

Capital invested $=B V$ of Debt $+B V$ of Equity

ROC pada tahun 2010 $=\frac{1.843 .326 .400}{5.076 .971 .579}=36.31 \%$

ROC pada tahun 2011 $=\frac{2.992 .874 .200}{6.890 .497 .789}=43.43 \%$
ROC pada tahun 2012

$=\frac{2.874 .808 .000}{7.915 .080 .364}=36.32 \%$

ROC pada tahun 2013

$=\frac{1.722 .270 .400}{7.402 .989 .159}=23.26 \%$

ROC pada tahun 2014

$=\frac{1.848 .158 .400}{9.904 .351 .933}=18.66 \%$

Sedangkan untuk menentukan Reinvestment Rate pada PT.Bukit Asam (Persero) Tbk dapat dilihat pada tabel 7 sebagai berikut :

\section{Tabel 7}

Reinvestment Rate PT.Bukit Asam (Persero) Tbk Tahun 2010-2014

\begin{tabular}{|c|c|c|c|c|}
\hline & $\begin{array}{c}\text { EBIT(1-tax) } \\
(1)\end{array}$ & $\begin{array}{c}\text { Capex } \\
(2)\end{array}$ & $\begin{array}{c}\text { NCWC } \\
(3)\end{array}$ & $\begin{array}{c}\text { Reinvestment Rate } \\
(4)=(2+3) /(1)\end{array}$ \\
\hline 2010 & 1.843 .326 .400 & 610.556 & 1.420 .856 & $110.20 \%$ \\
\hline 2011 & 2.992 .874 .200 & 583.112 & 1.825 .028 & $80.46 \%$ \\
\hline 2012 & 2.874 .808 .000 & 1.185 .213 & 2.311 .520 & $121.63 \%$ \\
\hline 2013 & 1.722 .270 .400 & 1.394 .080 & 2.329 .524 & $216.20 \%$ \\
\hline 2014 & 1.848 .158 .400 & 1.036 .002 & 2.472 .761 & $189.85 \%$ \\
\hline
\end{tabular}


Untuk menentukan Reinvestment Rate dapat menggunakan rumus sebagai berikut :

Reinvestment Rate $=$ Net Capex + Noncash Working Capital EBIT $(1-$ tax rate $)$

Reinvestment Rate tahun 2010 $=\frac{610.556 .000+1.420 .856 .000}{1.843 .326 .400}=110.20 \% \%$

Reinvestment Rate tahun 2011 $=\frac{583.112 .000+1.825 .028 .000}{2.992 .874 .200}=80.46 \%$

Reinvestment Rate tahun 2012 $=\frac{1.185 .213 .000+2.311 .520 .000}{2.874 .808 .000}=121.63 \%$
Reinvestment Rate tahun 2013 $=\frac{1.394 .080 .000+2.329 .524 .000}{1.722 .270 .400}=216.20 \%$

Reinvestment Rate tahun 2014 $=\frac{1.036 .002 .000+2.472 .761 .000}{1.848 .158 .400}=189.85 \%$

Untuk lebih jelasnya lagi dapat dilihat pada tabel 8 dibawah ini mengenai Reinvestment rate pada PT. Bukit Asam (Persero) Tbk. sedangkan untuk menentukan pertumbuhan yang diharapkan dari EBIT dapat dilihat pada tabel berikut :

Tabel 8

Expected growth Rate PT. Bukit Asam (persero) Tbk Tahun 2010-2014

\begin{tabular}{|c|c|c|c|}
\hline & $\begin{array}{c}\text { Reinvestment } \\
\text { Rate } \\
(1)\end{array}$ & $\begin{array}{c}\text { ROC after tax } \\
(2)\end{array}$ & $\begin{array}{c}\text { Expected Growth Rate } \\
(3)=(1)^{*}(2)\end{array}$ \\
\hline 2010 & $110.20 \%$ & $36.31 \%$ & $40.01 \%$ \\
\hline 2011 & $80.46 \%$ & $43.43 \%$ & $34.94 \%$ \\
\hline 2012 & $121.63 \%$ & $36.32 \%$ & $44.17 \%$ \\
\hline 2013 & $216.20 \%$ & $23.26 \%$ & $50.29 \%$ \\
\hline 2014 & $189.85 \%$ & $18.66 \%$ & $35.43 \%$ \\
\hline
\end{tabular}

Sumber : Laporan Keuangan PT. Bukit Asam (Persero) Tbk

Pada tabel 8 menjelaskan expected growth rate PT.Bukit Asam (Persero) Tbk pada tahun 2010 sebesar $40.01 \%$, dan pada tahun 2011 expected growth rate PT.Bukit Asam (Persero) Tbk mengalami penurunan sebesar 34.94\%. Pada tahun 2012 PT.Bukit Asam (Persero) Tbk mengalami kenaikan expected-nya sebesar $44.17 \%$ dan pada tahun selanjutnya juga mengalami kenaikan pada tahun 2013 sebesar 50.29\%. pada tahun 2014 expected growth rate turun sebesar $35.43 \%$.

\section{Skenario Return On Capital Yang Berubah dan Positif}

Dimana kenaikan pertumbuhan akan timbul bila ROC meningkat, dan tingkat pertumbuhan akan turun bila ROC turun. Maka dari itu dapat dilihat pada tabel sebagai berikut : 
Tabel 9

Expected Growth Rate PT. Bukit Asam (Persero) Tbk Tahun 2010-2014

\begin{tabular}{|c|c|c|c|c|}
\hline & ROCt & $\begin{array}{c}\text { Reinvestment } \\
\text { Rate } \\
(2)\end{array}$ & $\frac{\left(R O C_{t}-R O C_{t-1}\right)}{R O C_{t-1}}$ & $\begin{array}{c}\text { Expected } \\
\text { Growth Rate } \\
(4)=(1)^{*}(2)+(3)\end{array}$ \\
\hline 2010 & $36.31 \%$ & $110.20 \%$ & $-49.56 \%$ & $-9.55 \%$ \\
\hline 2011 & $3.43 \%$ & $80.46 \%$ & $19.61 \%$ & $54.55 \%$ \\
\hline 2012 & $36.32 \%$ & $121.63 \%$ & $-16.37 \%$ & $27.80 \%$ \\
\hline 2013 & $23.26 \%$ & $216.20 \%$ & $-35.95 \%$ & $14.33 \%$ \\
\hline 2014 & $18.66 \%$ & $189.85 \%$ & $-19.77 \%$ & $15.65 \%$ \\
\hline
\end{tabular}

Sumber : Laporan Keuangan PT. Bukit Asam (Persero) Tbk

Tingkat pertumbuhan yang diharapkan $=R O C t X$ Reinvestment rate $+\frac{\left(R O C_{t}-R O C_{t-1}\right)}{R O C_{t-1}}$

Expected growth rate tahun 2010 $=36.31 \% \times 110.20 \%+(-49.56 \%)=-9.55 \%$

Expected growth rate tahun 2011 $=43.43 \% \times 80.46 \%+19.61 \%=54.55 \%$

Expected growth rate tahun 2012

$=36.32 \% X 121.63 \%+(-16.37 \%)=27.80 \%$

Expected growth rate tahun 2013

$=23.26 \% X 216.20 \%+(-35.95 \%)=14.33 \%$

Expected growth rate tahun 2014

$=18.66 \% \times 189.85 \%+(-19.77 \%)=15.65 \%$

Pada tabel 9 di atas menjelaskan bahwa jika Return On Capital (ROC) yang berubah dan positif maka expected growth rate juga dapat berpengaruh. Pada tahun 2010 expected growth rate diperoleh sebesar $-9.55 \%$, dan pada tahun 2011 tingkat pertumbuhan yang diharapkan sebesar 54.55\%, pada tahun 2012 sebesar $27.80 \%$ sedangkan pada 2013 expected growth rate turun menjadi sebesar $14.33 \%$ pada tahun 2014 mengalami peningkatan expected growth rate-nya menjadi sebesar $15.65 \%$.

\section{Analisis Faktor Fundamental Pertumbuhan Perusahaan PT. Bukit Asam (Persero) Tbk.}

\section{Growth In Equity Earnings}

a. Pertumbuhan Net Income (NI) pada PT.Bukit Asam (Persero) Tbk yang mengalami fluktuasi naik turun dapat mempengaruhi tingkat pertumbuhan perusahaan. Dapat dilihat bahwa pertumbuhan net income pada PT.Bukit Asam (persero) Tbk. Dimana pada tahun 2010 net income sebesar 26,4\%. Pada tahun 2011 tingkat pertumbuhan net income sebesar $53,6 \%$ mengalami peningkatan $27.2 \%$ dari tahun 2010. Dan tahun 2012 tingkat pertumbuhan net income sebesar 6,0\% mengalami penurunan $47.6 \%$ dari tahun 2011.Pada tahun 2013 pertumbuhan net income sebesar $37,0 \%$ mengalami penurunan $31 \%$ dari tahun 2012. Dan pada tahun 2014 pertumbuhan net income sebesar $10,4 \% \quad$ mengalami peningkatan $26.6 \%$ dari tahun 2013 . Dapat dilihat bahwa Net Income pada PT.Bukit Asam (Persero) Tbk Pada tahun 2009 Net Income sebesar Rp.2.729.327. Pada tahun 2010 Net Income sebesar Rp.1.998.937 mengalami penurunan $26.76 \%$ dari tahun 2009. Dan Net Income pada tahun 2011 sebesar Rp.3.088.068 mengalami peningkatan $54.48 \%$ dari tahun 2010. Pada tahun 2012 Net Income sebesar Rp.2.909.421 mengalami penurunan $5.78 \%$ dari tahun 2011 . 
Pada tahun 2013 Net Income sebesar Rp.1.854.281 mengalami penurunan $36.26 \%$ dari tahun 2012. Pada tahun 2014 Net Income pada PT.Bukit Asam (persero) Tbk sebesar Rp.2.019.214 mengalami peningkatan $8.89 \%$ dari tahun 2013. Semakin tinggi Net Income yang diperoleh PT.Bukit Asam (Persero) Tbk maka akan berdampak kenaikan tingkat pertumbuhan perusahaan PT.Bukit Asam (Persero) Tbk.

b. Pertumbuhan yang diharapkan dari Net Income. Dapat dilihat bahwa pertumbuhan yang diharapkan dari net income pada PT.Bukit Asam (Persero) Tbk mengalami perubahan yang fluktuasi. Dimana pada tahun 2010 pertumbuhan yang diharapkan sebesar $105.30 \%$ dan pada tahun 2011 mengalami kenaikan pertumbuhan yang diharapkan dari net income sebesar 106.06\%. Pada tahun 2012 juga mengalami kenaikan sebesar $106.91 \%$, sedangkan pada tahun 2013 pertumbuhan yang diharapkan mengalami penurunan sebesar 82.39\% dan pada tahun 2014 juga mengalami penurunan terhadap pertumbuhan yang diharapkan dari net income sebesar $63.83 \%$.

\section{Growth in Operation Income}

a. Return on capital yang stabil, dimana expected growth rate PT.Bukit Asam (Persero) Tbk pada tahun 2010 sebesar $40.01 \%$, dan pada tahun 2011 expected growth rate PT.Bukit Asam (Persero) Tbk mengalami penurunan sebesar 34.94\%.Pada tahun 2012 PT.Bukit Asam (Persero) Tbk mengalami kenaikan expected-nya sebesar $44.17 \%$ dan pada tahun selanjutnya juga mengalami kenaikan pada tahun 2013 sebesar 50.29\%. pada tahun 2014 expected growth rate turun sebesar $35.43 \%$ dan juga untuk melihat pertumbuhan perusahaan juga dapat dilihat dari ROC. Dimana kenaikan tingkat pertumbuhan akan timbul bila Return On Capital (ROC) mengalami peningkatan, dan tingkat pertumbuhan akan turun bila Return On Capital (ROC) mengalami penurunan.

b. Dimana jika Return On Capital (ROC) yang berubah dan positif maka expected growth rate juga dapat berpengaruh. Pada tahun 2010 expected growth rate diperoleh sebesar $-9.55 \%$, dan pada tahun 2011 tingkat pertumbuhan yang diharapkan sebesar $54.55 \%$, pada tahun 2012 sebesar 27.80\% sedangkan pada 2013 expected growth rate turun menjadi sebesar $14.33 \%$ pada tahun 2014 mengalami peningkatan expected growth rate-nya menjadi sebesar $15.65 \%$.

Dengan melihat seberapa besar tingkat pertumbuhan didalam perusahaan, maka perusahaan dapat menentukan seberapa besar jumlah aset atau laba yang kedepannya digunakan untuk investasi baik untuk investasi jangka panjang maupun investasi jangka pendek. Dan juga analisis faktor fundamental pertumbuhan perusahaan berfungsi sebagai bahan kebijakan dalam menentukan keputusan investasi dimasa mendatang dengan melihat tingkat EPS (Earning Per Share) danNet Income yang di peroleh perusahaan. Dengan mengetahui besarmya pendapatan atau laba yang diterima perusahaan dapat memberikan informasi kepada para investor untuk menanamkan modalnya ke perusahaan. 
F. Kesimpulan dan Saran

1) Kesimpulan

Berdasarkan hasil penelitian yang dilakukan pada PT Bukit Asam (Persero),Tbk mengenai analisis faktor fundamentel pertumbuhan perusahaan, maka dapat diambil kesimpulan yang antara lain :

1. Growth In Equity Earnings

a. Pertumbuhan Net Income (NI) pada PT.Bukit Asam (Persero) Tbk yang mengalami fluktuasi naik turun dapat mempengaruhi tingkat pertumbuhan perusahaan. Dapat dilihat bahwa pertumbuhan net income pada PT.Bukit Asam (persero) Tbk. Dimana pada tahun 2010 net income sebesar 26,4\%. Pada tahun 2011 tingkat pertumbuhan net income sebesar $53,6 \%$ mengalami peningkatan $27.2 \%$ dari tahun 2010. Dan tahun 2012 tingkat pertumbuhan net income sebesar $6,0 \%$ mengalami penurunan $47.6 \%$ dari tahun 2011.Pada tahun 2013 pertumbuhan net income sebesar $37,0 \%$ mengalami penurunan $31 \%$ dari tahun 2012. Dan pada tahun 2014 pertumbuhan net income sebesar $10,4 \%$ mengalami peningkatan $26.6 \%$ dari tahun 2013 . Dapat dilihat bahwa Net Income pada PT.Bukit Asam (Persero) Tbk Pada tahun 2009 Net Income sebesar Rp.2.729.327. Pada tahun 2010 Net Income sebesar Rp.1.998.937 mengalami penurunan $26.76 \%$ dari tahun 2009. Dan Net Income pada tahun 2011 sebesar Rp.3.088.068 mengalami peningkatan $54.48 \%$ dari tahun 2010. Pada tahun 2012 Net Income sebesar Rp.2.909.421 mengalami penurunan $5.78 \%$ dari tahun 2011 . Pada tahun 2013 Net Income sebesar Rp.1.854.281 mengalami penurunan $36.26 \%$ dari tahun 2012 . Pada tahun 2014 Net Income pada
PT.Bukit Asam (persero) Tbk sebesar Rp.2.019.214 mengalami peningkatan $8.89 \%$ dari tahun 2013 . Semakin tinggi Net Income yang diperoleh PT.Bukit Asam (Persero) Tbk maka akan berdampak kenaikan tingkat pertumbuhan perusahaan PT.Bukit Asam (Persero) Tbk.

b. Pertumbuhan yang diharapkan dari Net Income. Dapat dilihat bahwa pertumbuhan yang diharapkan dari net income pada PT.Bukit Asam (Persero) Tbk mengalami perubahan yang fluktuasi. Dimana pada tahun 2010 pertumbuhan yang diharapkan sebesar $105.30 \%$ dan pada tahun 2011 mengalami kenaikan pertumbuhan yang diharapkan dari net income sebesar 106.06\%. Pada tahun 2012 juga mengalami kenaikan sebesar $106.91 \%$, sedangkan pada tahun 2013 pertumbuhan yang diharapkan mengalami penurunan sebesar $82.39 \%$ dan pada tahun 2014 juga mengalami penurunan terhadap pertumbuhan yang diharapkan dari net income sebesar $63.83 \%$.

2. Growth in Operation Income

a. Return on capital yang stabil, dimana expected growth rate PT.Bukit Asam (Persero) Tbk pada tahun 2010 sebesar $40.01 \%$, dan pada tahun 2011 expected growth rate PT.Bukit Asam (Persero) Tbk mengalami penurunan sebesar 34.94\%.Pada tahun 2012 PT.Bukit Asam (Persero) Tbk mengalami kenaikan expected-nya sebesar $44.17 \%$ dan pada tahun selanjutnya juga mengalami kenaikan pada tahun 2013 sebesar $50.29 \%$. pada tahun 2014 expected growth rate turun sebesar $35.43 \%$ dan juga untuk melihat pertumbuhan perusahaan juga dapat dilihat dari ROC. Dimana kenaikan tingkat pertumbuhan akan timbul bila 
Return On Capital (ROC) mengalami peningkatan, dan tingkat pertumbuhan akan turun bila Return On Capital (ROC) mengalami penurunan.

b. Dimana jika Return On Capital (ROC) yang berubah dan positif maka expected growth rate juga dapat berpengaruh. Pada tahun 2010 expected growth rate diperoleh sebesar $-9.55 \%$, dan pada tahun 2011 tingkat pertumbuhan yang diharapkan sebesar $54.55 \%$, pada tahun 2012 sebesar 27.80\% sedangkan pada 2013 expected growth rate turun menjadi sebesar $14.33 \%$ pada tahun 2014 mengalami peningkatan expected growth rate-nya menjadi sebesar $15.65 \%$.

\section{2) Saran}

Berdasarkan kesimpulan yang telah diuraikan di atas, maka saran yang dapat diberikan penulis yaitu :

1. Untuk para pengusaha atau investor yang ingin melakukan valuasi dalam menentukan tingkat pertumbuhan perusahaan dapat dengan melihat faktor fundamental perusahaan.

2. Untuk peneliti selanjutnya, disarankan untuk memperluas penelitian dengan cara memperbanyak jumlah perusahaan yang menjadi sampel dalam penelitian dan menambah variabel lainnya yang tidak digunakan dalam penelitian ini, dengan tetap berlandaskan pada penelitian-penelitian sebelumnya.

\section{DAFTAR PUSTAKA}

Harahap, Syofyan Syahri. 2013. Analisis Atas Laporan Keuangan. Raja Grafindo Persada. Jakarta Kaliapur, Sanjay, dan Mark A. Trombley. 1999. The Association Between Investment Opportunity Set Proxies and realized Growth. Journal Business \&Accounting 26, April/may, 505519.

Murhadi, Werner R. 2013. Analisis Laporan Keuangan Proyeksi Dan Valuasi Saham. Salemba Empat. Jakarta.

Sriwardany, 2007. Tesis Pengaruh Pertumbuhan Perusahaan Terhadap Kebijakan Struktur Modal Dan Dampaknya Terhadap Perubahan Harga Saham Pada Perusahaan Manufaktur Tbk. Universitas Sumatera Utara. Medan

Sugiyono. 2013. Metode Penelitian Bisnis. Bandung: Alfabeta 